\title{
Results of Routine Screening for Phenylketonuria in Early Infancy, Northern Ireland (1960-67)
}

\author{
N. A. J. CARSON, I. J. CARRÉ, and D. W. NEILL \\ From the Department of Child Health, The Queen's University, Belfast
}

The routine screening of newborns for phenylketonuria (PKU) was started in Northern Ireland during the early part of 1960 . The method used initially was the Phenistix/napkin test, i.e. a Phenistix strip (Ames Labs.), was pressed between the folds of a wet napkin. Tests were carried out by Health Visitors on infants aged between 3 and 6 weeks. Because this screening procedure was not adopted by Public Health Authorities of all six Counties at the same time, many newborns in the Province were not screened during the early part of this survey. This accounts for the fact that the number of children screened between January 1960 and December 1963 constitutes only slightly over $50 \%$ of the total births during this period (Table).

The results of Phenistix testing proved disappointing, and clearly demonstrated the unreliability of the test as a screening procedure. Whereas 2 patients with phenylketonuria were discovered using this screening technique during 1960-63, 4 others, recorded as having a negative Phenistix/ napkin reaction, were later shown to be suffering from the disorder. Yet, laboratory trials using fresh samples of liquid urine from a large number of known phenylketonuric patients all gave a positive reaction on testing with Phenistix strips. It seemed, therefore, that the recorded false negative Phenistix/napkin screening results were more likely to have been due to errors in technique in performing

Received December 18, 1967. the cest than to some specific insensitivity of the test itself. With this in mind we carried out the following simple laboratory experiments.

A small square of thick filter paper was placed between the folds of a number of napkins, on each of which a quantity of fresh phenylketonuric urine was then poured. The urine samples used in these tests were of two types: (1) urine from untreated phenylketonuric patients; (2) urine from healthy children to which had been added phenylpyruvic acid. The wet napkins (with enclosed filter paper) were next placed in a plastic bag. Some of these bags were kept at room temperature, while others were incubated at $37^{\circ} \mathrm{C}$. After periods varying from 1 to 18 hours, the napkins were taken out of the plastic bags. The filter papers were then removed from the napkins and dried, some at room temperature, some at $100^{\circ} \mathrm{C}$. and others at $40^{\circ} \mathrm{C}$. All gave strongly positive reactions with $5 \%$ aqueous ferric chloride. The dried filter papers were kept in an envelope and retested at frequent intervals. The napkins, which were left exposed at room temperature, were tested every few hours, (a) by pressing a Phenistix strip between the folds, and (b) by direct application of a few drops of $5 \%$ aqueous ferric chloride. The results of this experiment showed that the napkins gave negative results (with both Phenistix and ferric chloride) within 24 hours of removal from the plastic bag. On the other hand, the filter papers, regardless of how dried, retained their reacting properties to

TABLE

Results of Screening Newborns for Phenylketonuria

\begin{tabular}{|c|c|c|c|c|c|c|}
\hline Period & Method of Testing & $\begin{array}{c}\text { Approximate } \\
\text { Number of } \\
\text { Newborn } \\
\text { Babies } \\
\text { Tested }\end{array}$ & $\begin{array}{c}\text { Number of } \\
\text { PKU } \\
\text { Babies } \\
\text { Diagnosed }\end{array}$ & $\begin{array}{c}\text { Number of } \\
\text { False } \\
\text { Negatives }\end{array}$ & $\begin{array}{l}\text { Born into } \\
\text { Known } \\
\text { PKU } \\
\text { Family }\end{array}$ & $\begin{array}{c}\text { Total } \\
\text { Number } \\
\text { of New } \\
\text { Cases }\end{array}$ \\
\hline $\begin{array}{l}\text { January } 1960 \text { to December } 1963 \\
\text { January } 1964 \text { to September } 1967\end{array}$ & $\begin{array}{l}\text { Phenistix/napkin } \\
\text { Filter paper } / \mathrm{FeCl}_{3}\end{array}$ & $\begin{array}{r}74,100 \\
127,300\end{array}$ & $\begin{array}{l}2 \\
6\end{array}$ & $\begin{array}{l}4 \\
1\end{array}$ & $\begin{array}{l}3 \\
6\end{array}$ & $\begin{array}{r}9 \\
13\end{array}$ \\
\hline
\end{tabular}

^ Excludes PKU babies born into known PKU families, since these were anticipated and hence investigated by estimating phenylalanine levels in blood and urine. 
aqueous $5 \%$ ferric chloride for up to one month.

In view of these observations, it was decided to replace the Phenistix/napkin test by the ferric chloride/filter paper test as a screening procedure. Mothers were instructed by Health Visitors to place a $5 \mathrm{~cm}$. (2 in.) square of thick filter paper (Whatman $3 \mathrm{~mm}$.) between the folds of a napkin. After the baby had passed urine, the wet filter paper was removed, and dried either by allowing to stand at room temperature or by holding in front of the fire. The dry filter paper was then placed in an envelope, and either posted direct to the Health Centre, or put aside to await collection, depending on local arrangements. These papers were then tested in batches at the Local Health Centre with $5 \%$ aqueous ferric chloride. The substitution of this screening test for the Phenistix/napkin test involved little alteration in administrative procedure, and was effected in all areas by the end of 1963.

The results of this form of testing over the last four years have been encouraging, and have indicated its superiority to the Phenistix/napkin test as a screening procedure. So far 6 patients with phenylketonuuria have been discovered, while only 1 is known to have been missed (Table). This one false negative occurred in an uncooperative problem family, and it is very doubtful whether the mother did in fact carry out the instruction to place the filter paper in the baby's napkin. This is, of course, an inherent weakness of screening tests of this type which depend on the co-operation of the parent in producing a specimen for analysis.

Definite conclusions are obviously impossible on such small figures, especially as missed cases may not yet have come to light, though we believe that in few, if any, has this happened. We base this belief on our experience that 4 of the 5 cases that were missed at the initial screening were subsequently diagnosed before attaining the age of 16 months. Furthermore, it is likely that missed cases would have come to our notice even sooner during the latter part of the survey as a result of the increased awareness of this disorder.

While evidence to date suggests that the testing of urine-impregnated filter paper squares with 5\% aqueous ferric chloride is a superior screening test to Phenistix as carried out by Health Visitors, the test clearly suffers from the same disadvantage in that it depends on the development of the keto-acid pathway of phenylalanine metabolism.

Phenylketonuria should be regarded as only one of a number of inborn errors of amino acid metabolism for which it is desirable to screen all newborn infants. In our opinion such screening will ultimately involve the use of automated analytical equipment capable of measuring the concentration of a wide range of amino acids in the blood and urine of the newborn child, and automatically processing the data so obtained. Equipment of this type is likely to be available in the near future, and pending its evaluation in suitable pilot studies, all the techniques presently used for detecting phenylketonuria should be regarded as interim measures.

\section{Summary and Conclusions}

On the basis of our observations we regard the ferric chloride/filter paper method of screening for phenylketonuria as being more reliable than the commonly used Phenistix/napkin test. For this reason we feel it is a preferable interim form of screening procedure pending the introduction of more sophisticated and completely automated screening methods. The screening technique as currently employed in Northern Ireland has the additional merit that it can be adopted in any area which has hitherto relied on the Phenistix test, with little administrative inconvenience.

We wish to acknowledge the co-operation of all the Medical Officers of Health, and their staff. 